\title{
APPLYING IIOT AND AI - OPPORTUNITIES, REQUIREMENTS AND CHALLENGES FOR INDUSTRIAL MACHINE AND EQUIPMENT MANUFACTURERS TO EXPAND THEIR SERVICES
}

\section{Qvist-Sørensen, P.}

Peter Qvist-Sørensen / Zurich University of Applied Sciences, School of Management and Law, Department International Business, Center for International Industrial Solutions, Theaterstrasse 15, CH-8401 Winterthur, Switzerland, qvis@zhaw.ch.

\begin{abstract}
Theroretically, servitization benefits industrial companies to generate more revenue, integrate themselves deeper into the value chains of their customers and improves the competitiveness. The ongoing digital transformation can enable servitization towards more advanced services with a more customer centric view. Macro economically, the industrial sector is very important for most of the developed countries. The digital transformation is posing a triple challenge to the machining and equipment manufacturers and will require a continued development of the existing business models, a change of organizational structures and a strong leadership to remain successful. The companies will need to reevaluate their market justification and define their value proposition to both existing and potentially new customers. New skills are required as data and analytics, represented by IloT and Al, will play an ever-larger role in the companies' interaction with their present and new customers. For the industrial companies, servitization is both linked to higher risk and to a higher earnings potential.

Implications for Central European audience: The implications for Central European industrial companies of the ongoing digitalisation and servitization will be profound. The European car industry is undergoing significant changes and not only due to E-mobility. Also Products-as-Service will have an impact on their whole value chain. The industrial sector in general and the machining industry in particular will need to re-assess its business models and revenue generation. In addition, senior management is already confronted with the need for both new skill-sets and possibly more agile organisational structures, where the industrial mind-set will be challenged by new service models and the thinking of the digital natives.
\end{abstract}

Keywords: Servitization; SSPs; SSCs; machining and equipment manufacturers; digital transformation; Industrial services; IloT; Artificial intelligence

JEL Classification: M15 


\section{Introduction}

"Company CEOs, who believe that the digital-industrial "hype" is a temporary fad, or believe that their company is immune to the disruptiveness of the digitalisation of industries, are confronted with the following two questions: First, how could I miss this revolution? Secondly, how can I catch up with the companies, which are already thinking digitally and are on to new business models...", Ulrich Spiesshofer, CEO (2013-2019) ABB in Neue Zürcher Zeitung April 17 $7^{\text {th }}, 2017$ (translated into English by the author).

In this paper the position taken will be that in the OECD countries the industrial machining and equipment companies' continued success in starving off the competition from emerging (Asian) countries) is neither a discussion about the degree of servitization, nor is the digital transformation a clear path to success. Rather, the continued success of these companies depends on the ability to answer the fundamental question raised by Theodore Levitt (1960) in his seminal paper "Marketing Myopia": "What business are you really in?"

Based on examples from the railroad, oil and electronics industries, Levitt argued that companies need to be sure that they understand their customers real needs and that there can be a fundamental gap between these real needs and what the companies themselves define as offerings to meet those needs. Levitt explains, among others, the demise of the American railroad industry as a result of narrow-minded executives focusing on only providing railroad services, rather than transportation services, thus not timely acknowledging and embracing the threats from new technologies (trucks, cars, buses).

Relating Levitt's fundamental question to the machining and equipment industry, the companies will possibly need to re-consider their value proposition for existing and new customers, using servitization models and digital technologies as enablers while identifying market opportunities and internal constraints.

This research paper will therefore build on empirical evidence and recent seminal and academic papers discussing the links between machining and equipment manufacturers' (industrial companies) (changing) business models, level of servitization, organizational structures, the application of the Industrial Internet of Things (IloT) and Artificial Intelligence (Al) and the corresponding impact on sales and profitability.

Building on an analysis of selected industrial companies, a case will be made that the ongoing digital transformation, especially relying on IloT and Artificial Intelligence ( $\mathrm{Al}$ ) as enabling technologies, can be a fundamental game-changer for machining and equipment companies, either by opening up a range of new business and corresponding earnings opportunities, or by threatening their existing business models including their servitization offerings.

Focusing on B2B machinery and equipment manufacturers (ME), as opposed to suppliers of modules and components (Fischer 2012), the following two questions will be addressed:

1) How can digitalization (Big Data, Analytics, Al, IloT) change the business model of the ME companies from a Product-Service (P-S) model towards an outputperformance model? 
2) Which services can be offered through digitalization and how would these (services) impact the present and the future business and revenue models for the ME companies?

General Electric defines IloT ${ }^{1}$ as, "... the network of a multitude of devices connected by communications technologies that results in systems that can monitor, collect, exchange, analyze, and deliver valuable new insights like never before."

Big Data is data which according to IBM ${ }^{2}$ meets the requirements of the five "Vs": Value of the data, the Variety of sources from which the data originate, the Velocity of the data transfer, the Volume of data transmitted and analyzed and Veracity guaranteeing the quality of the data.

Digitalization, used interchangeably to include IloT, AI, Big Data, Analytics and Industry 4.0 (defined in detail on page 5) offers the opportunity for industrial manufacturing (machine) companies to provide their customers with new performance-based offerings, possibly linked to pay-per-use financing schemes, or continued optimization in both the B2B and, with the addition of the consumer dimension, the B2B2C value chain.

Thus, the digital technologies are viewed as enablers and necessary (but not the only) preconditions for the successful implementation of new services.

\section{Literature Review}

Since its inception by Vandermerwe (1988), the concept of "servitization of business" seems to have become an academic standard terminology (a Web of Science and ScienceDirect search for "servitization" yields 582 and 690 results, respectively) describing industrial companies' strategic opportunities to generate additional revenue from providing services to their customers.

The academic concept of manufacturing companies offering customer solutions rather than their equipment can be traced back to Harvard University Marketing Professor Theodore Levitt when in the 1960s he made the famous quoted statement "People don't want a quarter-inch drill. They want a quarter-inch hole!" (Gallo, 2016).

Mathieu (2001) has presented clear distinctions between different types of industrial services, namely the services that are supporting the products (SSPs) and services supporting the clients (SSCs). Whereas traditional MRO services (Maintenance, Repair and Overhaul) belong to the first category, SSCs are referring to types of services which will support the customers in becoming more productive (e.g. predictive maintenance), efficient (real-time monitoring and management of production processes) and focusing on their core competencies by integrating the suppliers into the value chain (Ambroise, 2018).

The definitions of industrial companies' service offerings have developed over time, especially since the introduction of the Product-Service System (PSS) models by Mont (2002). From an environmental perspective, Mont argues that consumers are only willing to reduce their consumption (of materials) if other types of products, i.e. services are offered instead.

${ }^{1}$ https://www.ge.com/digital/blog/

${ }^{2}$ https://www.ibm.com/blogs/watson-health/the-5-vs-of-big-datal 
The manufacturing industry has, according to Mont, already undergone a fundamental transformation away from a pure manufacturing mind-set of mass production towards mass customization, incorporating additional services into the products themselves. However, not necessarily resulting in any reduction of materials, as pointed out by Mont.

Though Mont's focus is the reduction of consumption's environmental footprint, the PSS models envision the offerings of integrated solutions encompassing products, services, infrastructure and supporting networks. The manufacturers have the opportunity to add more (service) value to their equipment, to innovate, to offer long-term upgrades and refurbishments, and to assume the responsibility for the full product life cycle of the equipment. Ownership models become more fluid, as customers may choose pay-per-use or output based payment schemes, rather than choosing a traditional purchase of the equipment.

Mont points out that a change towards a PSS model requires a fundamental shift in the company's market approach, organization and company culture. Inter- and intra-cultural changes are required to interact efficiently, profitably and for the long term with both the customers and the suppliers in the whole ecosystem. The change in ownership models will have a significant impact on short-term profitability, which can only be compensated by offering additional services.

Lately, Ambroise (2018) has added to Mont's findings and among others described the shift among suppliers of manufacturing equipment from getting paid for their machines to being paid on the output these machines produce, i.e. the suppliers remain owners of their own produced machines.

As documented by Fischer (2012) these machining and equipment manufacturers today basically make their profits on services and spare parts, whereas the sales of equipment at best is a break-even business serving the purpose of replacing or expanding the installed base (for future service revenue).

Service is therefore a model by which machine and equipment manufacturers can meet the following objectives:

- $\quad$ Generating revenue and profits,

- Gaining a competitive differentiation advantage, and

- $\quad$ Obtaining a closer relationship with their customers.

Though, as mentioned previously, a significant amount of literature has been written in the last decades about the opportunities for manufacturing companies to expand into providing more services (aka servitization), services still only account for a relatively small part of their total revenue. Gebauer (2006), having analyzed the revenue composition of 199 manufacturing companies in Germany and Switzerland, was able to document that only 11 $\%$ of the companies generated more that $40 \%$ of their revenue from services. More than $65 \%$ of the companies generated $20 \%$ or less revenue from services.

Vorozheikin (2018) has in a Master's Thesis and a paper to be published, analyzed 77 publicly listed companies (S \& P 500 and MSCl Europe ETF) producing industrial machinery and equipment to look for any correlation between company valuation and the 
degree of advanced services offered.

Based on their annual reports, the company valuations were measured as the development in the Tobin's q ratio, over a 17-year period (2000-2017). Tobin's q (Bontis, 1999) refers to the measurement of the relationship between a company's market value (share price $x$ number of shares) and its book value (replacement costs of assets).

The degree of advanced services was measured by quantifying the use in the same annual reports of words such as "service revenue", "risk and revenue sharing", "service solutions" over the same period.

The study finds a clear correlation between the degree of servitization and the stock market valuation relative to their book value of their assets (Tobin's q). More servitized companies offering advanced services had a higher Tobin's q than companies offering more basic or intermediate services, such as supply of spare parts and standard MRO services.

However, the causality between more servitized and more valuable is statistically not verifiable, leaving the question open if more successful (higher valuation) industrial companies are more successful because they provide more advanced services, or simply because their business models in general are more aligned with their customers' needs, which in turn implies offering more services.

The ongoing digital transformation with the interconnectivity of machines, customers, consumers and suppliers in the Industrial Internet of Things, and the increasing computational power enabling the algorithms in artificial intelligence and machine learning, is adding yet another layer of complexity to these industrial companies.

In a recent publication, OECD (2017) makes a distinction between digital technologies and new processes. Such digital technologies include 3D printing, IloT (digital connectivity) and advanced robotics, whereas new processes focus on data driven production and machine learning and - Al (Artificial intelligence).

Industry 4.0, or advanced manufacturing, is referring to the digitalization of production with interconnected digital technologies, linking low cost sensors and new control devices to data science and machine learning (Bauer, 2015).

Not only will Big Data, as described by Lee (2014), provide ample opportunities for industrial companies to become more successful, but will for some companies be a downward turning point due to external threats from known and unknown competitors and because the companies cannot make the organizational changes needed to embrace the digital transformation (Wade, 2015).

Large industrial companies, such as Roll-Royce (2016, 2018), ABB (2018), Voith (2018) and Siemens have seen the "writing on the wall" and have undertaken fundamental changes in their business models and organizational structures and are establishing strategic alliances with digital companies such as IBM (Siemens 2016), Microsoft ${ }^{3}$ and Atos (Siemens, 2018). Other large industrial companies, such as General Electric (Editorial, 2018), are struggling to undergo the timely and needed changes.

${ }^{3}$ https://news.microsoft.com/2016/10/03/abb-and-microsoft-partner-to-drive-digital-industrial-transformation/ 
At the macroeconomic level, the OECD countries are aware not only of the importance of preserving their industries, but also the challenges that companies and societies are facing when it comes to maintaining or even expanding advanced manufacturing.

According to the European Parliament (Davies, 2015), the European manufacturing industry employs more than 33 million people and accounts for more than $80 \%$ of all exports.

Whereas the narrow definition of manufacturing in the United States only accounts for $11.7 \%$ of GDP (Manufacturing USA 2018), the broad definition of the manufacturing industry, including related services, still accounts for more than 35\% of GDP (Scott 2015), but with falling employment (Muro, 2015).

At the same time, the European industrial (manufacturing) sector in general is increasingly facing competition from Asian manufacturers (Davies, 2015), which are advancing rapidly in their high value-added capabilities (UNIDO, 2018), i.e. quality of machines and production features.

The OECD countries (OECD, 2017) have recognized not only the opportunities that the digital transformation will offer to their countries, but also the societal and macroeconomic risks linked to the permanent loss of high value-added manufacturing and industrial facilities, should these countries not be able to undertake the transformation in a timely manner.

Realizing the importance of the ongoing digital transformation and its implications for the manufacturing industry (European commission, 2016), the European Union has in the current Horizon 2020 program allocated more than M-EUR 17.000 to advance European industrial leadership ${ }^{4}$.

In the United States the national program Manufacturing USA, spearheaded by the National Institute of Standards and Technology (NIST), the Department of Defense (DOD) and the Department of Energy (DOE), has an annual budget of M-USD 3.400 to support 14 national manufacturing innovation institutes. The objectives of the program are among others to increase American competitiveness in manufacturing, assist in the implementation of innovative technologies and train the workforce in advanced manufacturing (Manufacturing USA, 2018).

The industrial machining and equipment manufacturers go about the digital transformation in rather different ways.

A new study for Swissmem (Meylan et al., 2019), co-authored by this author, compared a literature analysis with the results from on-site interviews with C-level management of some 15 leading industrial companies in Switzerland, regarding the past and present changes in the activities along the companies' value chains in order to develop future five- and 20-year scenarios. Swissmem is the Swiss Association for SMEs and large companies in Switzerland's mechanical and electrical engineering industries (MEM industries) and related technology-oriented sectors.

${ }^{4}$ http://ec.europa.eu/research/participants/docs/h2020-funding-guide/grants/applying-for-funding/find-a-call/h2020structure-and-budget en.htm - IndLs 
Based on the results from the interviews and the systematic allocation of present and future functions along the value chain, it was possible to identify two very distinct company approaches to the digital transformation. One group of companies sees the digital technologies as enablers to improve internal efficiencies (production, logistics, etc.), whereas the second group of companies sees the digital technologies as enablers to improve their servitization and to develop a closer relationship with their customers (connectivity, predictive maintenance, optimization, etc.).

Summarizing the aforementioned findings, industrial machining and equipment manufacturers can move closer to their customers and integrate themselves in the customers' value chains by offering SSCs and advanced services. This move can add significant value to the companies, but is riskier, requires an adjustment of the organization and probably a change in the business model.

Research conducted by Mont (2002, 2006), Benedittini (2015) and Ambroise (2018) have discussed not only the business opportunities, but more fundamentally the risks, the lack of additional earnings, the strategic focus areas and the organizational challenges of these industrial companies when they provide additional services linked to their core business of selling machines and equipment.

Though the opportunities for profits and closer customer proximity would seem to be obvious, these opportunities come with higher risks, as highlighted by Benedettini (2015) in the paper "Why do Servitized Firms Fail? A Risk-Based Explanation".

The paper analyzed 129 bankruptcies of manufacturing companies in order to evaluate the correlation (if any) between the companies offering services in general and the risk of going bankrupt, compared to other companies offering no, or little services.

The paper identifies four major internal risks of failure for companies entering into services,

1) Inability to restructure

2) High cost of introducing new products and services

3) Cost of expansion through acquisition

4) Operational inefficiencies

In addition, the paper discusses whether offering Services Supporting Products (SSP) is less risky than offering Services Supporting Customers (SSC), without reaching a statistically significant conclusion.

Here the premise is that SSPs are closer to the machine and equipment company's core competencies (knowing their own equipment), than the SSC offerings, where the company gets itself involved in, or takes over a part of, the customer's internal production and optimization processes.

Learning from these company failures and associated internal risks, the question is whether the time has come to rethink the business model for many manufacturers, - away from producing products and towards offering advanced output/performance and solutions.

IoT and $\mathrm{Al}$ offer either the opportunity to move closer to the customers or pose the threat of losing more of the service business. 
The latter is supported by Lay's findings (2014) regarding service offerings from the "European Manufacturing Survey 2009", containing responses from 3,634 manufacturing companies in Europe.

Not surprisingly, 85-88 per cent of the machinery companies offer design consultation and technical documentation, whereas 74 per cent offer maintenance and repair services.

However, only 42.7 per cent of the companies offer software solutions. Third party vendors thus provide more than 57 per cent of the software developments and interconnectivity solutions.

The importance of providing comprehensive services is supported by Kohtamäki (2013), which analyzed the "non-linear relationship between industrial service offering and sales growth".

The paper contains a comprehensive summary of industrial service offerings from previous findings and, based on statistical analyses, concludes that the

"direct effects of service offering activity were positive but also non-linear, suggesting that firms should consider moving toward full-service provision, developing a comprehensive service offering and value propositions so as to provide integrated solutions, to co-produce offerings and co-create customer's experience".

There are clear indications that customers expect of their machinery and equipment suppliers not only Service Supporting Products (SSPs), but also Service Supporting Clients (SSCs), even new SSCs. This is clearly documented through company interviews by Hakanen (2014).

However, in order for companies to become more successful in providing services, the management and key account managers need to develop a "customer-centric servitization" model on how to integrate themselves into their customers value chain and organization.

Hakanen (2014) recommends conducting detailed interviews with both existing and potential new customers to learn about their specific needs and how the companies can meet or exceed these needs.

In other words, the importance of integrating the services into the customer's own value chain should not be underestimated.

Another decisive factor for servitizing machining and equipment manufacturing companies is the organization.

Ambroise (2018) recently documented that the right organization is a very important component for an industrial company to offer services profitably. Depending on the different servitization strategies, the organization (and its mind-set) will need to be structured accordingly.

The senior management of 184 mainly smaller industrial companies were interviewed regarding their servitization strategies and their organizational structures. In addition, the companies' financial results were retrieved and analyzed.

Correlating the servitization strategies with the financial results, the corresponding organizational structures were able to explain some $27 \%-31 \%$ of the variation in the 
operating margin ratio (EBITDA/sales). The results possibly need to take into account that the interviewed companies were relatively small. Thirty-nine percent of the industrial companies had less than 10 employees and another $49 \%$ had between 10 and 40 employees.

For a servitization strategy to be financially successful, the right organization with the needed customer orientation and service mind-set are paramount.

Ambroise (2018) therefore concludes that just offering more services, without reconfiguring the company's activities, organization and business model, will not yield the expected positive financial impact.

\section{An Emerging Paradigm}

Over years, the machining and equipment manufacturing companies have accumulated a wealth of information about their customers and these customers' production processes and needs.

From a service perspective, however, most industrial companies limit their service portfolio to providing classical services on their products (spare parts, repair, overhaul and preventive maintenance). Using Gebauer's (2006) results as a proxy for defining the machining and equipment manufacturers' business models, it can therefore be construed that many industrial companies have built their business success on supplying excellent systems/products/parts to other businesses (B2B), rather than services.

The know-how and information about the customer needs and production processes related to the supplied products are, however often given away for free in order to secure an order for their products.

Simultaneously, the concepts of the Industrial Internet of Things, used interchangeably with Industry 4.0 (Davies, 2015) are emerging, which enable suppliers and customers to link together in completely new ways. Citing the German Chancellor Merkel Davies (2015) defines Industry 4.0 as "the comprehensive transformation of the whole sphere of industrial production through the merging of digital technology and the internet with conventional industry".

For the first time, industrial suppliers have the possibility to turn big data flows into useful information and profitable business models using machine learning and Artificial Intelligence $(\mathrm{Al})$.

The interconnectivity of devices, machinery, sensors, augmented reality, analytics, manmachine interfaces, customers and system providers are opening up hitherto unprecedented business opportunities for industrial companies to maintain or increase their competitiveness.

In addition, additive manufacturing (3D printing) is in certain industries creating disruptive production methods, which are reducing supply lines and often eliminating the advantages of economies of scale. 
With the advent and convergence of high-performance digital technologies, the topic "servitization" in the era of digitalization, Big Data and machine learning (AI) is as pertinent as ever.

Some major companies are already reacting, like the American companies Johnson Controls' and Tyco's 33 billion USD merger in order to be 'Uniquely positioned to capitalize on convergence"... of ... "Internet of Things expanding existing markets and defining new markets \& ecosystems" (Johnson Controls, 2016).

The German Siemens and IBM have announced to integrate Watson Analytics into the MindSphere IloT cloud-based operating system to make better and timelier use of data provided by sensors (Siemens, 2016).

The German machine manufacturer Voith, described below, divested of its Industrial Services Division and instead founded a new Digital Solutions Division with the objective of becoming the preferred partner for the (Industrial) Internet of Things in mechanical and plant engineering (Voith, 2016).

At the same time, machining companies are being confronted with new demands from their customers and are facing the challenge of developing a new business model and getting paid for integrated service solutions.

During the interview phase for the Swissmem study (Meylan et al., 2019), two large companies explained how they need to adapt their business models to new demands from major customers.

One company supplies machinery to the automobile industry. One of the large German car manufacturers has recently informed the Swiss manufacturer that if they want to continue to be a supplier, they will need to take over in full the part of the production line where their machines are in use, meaning production and service. The supplier will be paid by volume output.

Another Swiss company supplying the printing industry has also been requested by their customer, a large publisher, to take over their specific part of the production process. Payment will be based on volume produced. In return, the supplier will be guaranteed a certain minimum volume for a specific period of time.

In both cases, the companies are being invited to share the value chain with their customers, as also described by Ambroise (2018).

However, this advanced type of servitization has significant consequences for the manufacturers.

First, the suppliers will not be selling their equipment to their customers. Either the manufacturers will need to keep the equipment on their own balance sheet or offload the machines to third party financial institutions.

Secondly, the manufacturers will be responsible for the full part of the production process, using the equipment. This means being responsible for volume, quality, efficiency, throughput and the operators. 
Thirdly, as the machining manufacturers are becoming responsible for servicing their own equipment their R\&D departments will be looking into ways of improving the lifetime of the wearable parts in order to reduce downtime and servicing costs. This runs contrary to the traditional business model of selling maintenance services and parts.

Fourthly, the digital transformation with IloT and Al can accelerate and assist these suppliers in leveraging the accumulated knowledge from this value chain integration into being able to offer similar services to other customers.

\subsection{Voith - a Company Example}

The German company Voith $(2016,2017,2018)$ has taken a major step towards positioning itself as a leader offering solutions for the industrial digital transformation, fulfilling the demand for advanced services and focusing on the entire life cycle for the sold and already installed machinery. Privately held and with an annual revenue of app. M-EUR 4,000, Voith is a leading producer of machines and equipment to a vast number of industries, such as paper, energy, transportation, oil \& gas, mining and cement.

In 2016, Voith divested of its Voith Industrial Services division with 17,600 employees and 200 locations worldwide.

The same year Voith founded Voith Digital Solutions (today Voith Digital Ventures with more than 2,200 employees) with the clear objective to "become the preferred partner for the Internet of Things in mechanical and plant engineering" (Voith 2016) and to merge its expertise in automation and IT with its industrial know-how in energy, paper and transportation (Voith, 2018).

Wanting to accompany existing and new customers on their digital transformation journey in order to increase production and improve efficiency, the company stated the following three strategic directions (Voith, 2016):

1) Supplementing the existing product portfolio with additional capabilities that offer customers extended functions and added value

2) Development of new digital solutions in traditional core markets

3) Development of new products and business models for markets and industries to date not covered by Voith.

To support these strategic directions, Voith has since 2016,

1) Launched OnCumulus, a Cloud based IloT platform offering customers a centralized access point for the existing stand-alone machines,

2) Launched merQbiz, an E-commerce platform for paper mills to trade recovered paper (Voith, 2017),

3) Acquired a $60 \%$ stake in Ray Sono, a German company offering digital service communication solutions, and

4) Founded Voith Robotics in a joint venture with Franka Emika, a German robotics start-up company.

As indicated in Table 1, services play an ever-increasing part of total revenue, having increased more than $14 \%$ during the last four years and now accounting for almost $32 \%$ of 
total revenue. The sales of machines and equipment has in the same period decreased by more than $8 \%$ - although currency fluctuations have an impact too (Voith, 2018).

Digital Solutions (Ventures) account for app. $7 \%$ of total sales and more than $20 \%$ of the service revenue.

Table 1 | Voith Annual Revenue 2014/15 to 2017/18

\begin{tabular}{|c|c|c|c|c|c|c|c|c|c|}
\hline \multirow{2}{*}{$\begin{array}{l}\text { M-EUR } \\
\text { Machinery }\end{array}$} & \multicolumn{2}{|c|}{$2014 / 15$} & \multicolumn{2}{|c|}{$2015 / 16$} & \multicolumn{2}{|c|}{$2016 / 17$} & \multicolumn{2}{|c|}{$2017 / 18$} & \multirow{2}{*}{$\begin{array}{r}\text { Period } \\
-8.3 \%\end{array}$} \\
\hline & $3,124.2$ & $72.6 \%$ & $3,042.4$ & $71.5 \%$ & $2,941.3$ & $69.6 \%$ & $2,864.9$ & $68.1 \%$ & \\
\hline Services & $1,178.1$ & $27.4 \%$ & $1,210.0$ & $28.5 \%$ & $1,282.7$ & $30.4 \%$ & $1,344.2$ & $31.9 \%$ & $14.1 \%$ \\
\hline Voith Total & $4,302.3$ & $100.0 \%$ & $4,252.4$ & $100.0 \%$ & $4,224.0$ & $100.0 \%$ & $4,209.1$ & $100.0 \%$ & $-2.2 \%$ \\
\hline $\begin{array}{l}\text { Profit from } \\
\text { Operations }\end{array}$ & 270.0 & $6.3 \%$ & 275.0 & $6.5 \%$ & 254.0 & $6.0 \%$ & 211.0 & $5.0 \%$ & $-21.9 \%$ \\
\hline \multicolumn{10}{|l|}{$\begin{array}{l}\text { Digital } \\
\text { Offerings }\end{array}$} \\
\hline - Hydro & & & & & 131.0 & $43.8 \%$ & 101.0 & $37.0 \%$ & $-22.9 \%$ \\
\hline - Paper & & & & & 87.0 & $29.1 \%$ & 98.0 & $35.9 \%$ & $12.6 \%$ \\
\hline - Turbo & & & & & 68.0 & $22.7 \%$ & 34.0 & $12.5 \%$ & $-50.0 \%$ \\
\hline $\begin{array}{l}\text { - Digital } \\
\text { Solutions }\end{array}$ & & & & & 13.0 & $4.3 \%$ & 40.0 & $14.7 \%$ & $207.7 \%$ \\
\hline $\begin{array}{l}\text { Voith Digital } \\
\text { Total }\end{array}$ & & & & & 299.0 & $100.0 \%$ & 273.0 & $100.0 \%$ & $-8.7 \%$ \\
\hline $\begin{array}{l}\% \text { of Voith } \\
\text { Total }\end{array}$ & & & & & $7.1 \%$ & & $6.5 \%$ & & $-8.4 \%$ \\
\hline$\%$ of Services & & & & & $23.3 \%$ & & $20.3 \%$ & & $-12.9 \%$ \\
\hline
\end{tabular}

Sources: Voith Annual Reports $(2016,2017,2018)$

Voith (2018) is therefore recognizing that there is a market need for more advanced services, including new applications and business models to new customer segments. To provide these services, Voith will need to hire more people with the right qualifications, especially with competencies in IloT, and has thus embarked on a program to attract and retain these people.

In line with Ambroise' findings (2018), Voith is internally preparing for a more complex business environment by adjusting and encouraging the global organization to find new ways to collaborate and communicate in networks (Voith, 2018).

Acknowledging that Voith Digital Ventures is still in a start-up phase and thus loss-making to the tune of more than M-EUR 40 annually, Voith is also aware of the inherent risks of not being able to turn the ongoing digital transformation into a profitable business model and the Corporate Board of Management is monitoring the development accordingly, as stated in their annual report (Voith 2018). 


\subsection{Rolls-Royce Civil Aerospace - a Company Example}

Another example is Rolls-Royce Civil Aerospace (UK).

Since 1962, Rolls-Royce has offered their aviation customers Power-by-the-Hour as a Preventive Maintenance model, i.e. fixed rates MROs (Maintenance, Repair and Overhaul), based on hours flown. Rolls-Royce was thereby able to schedule fixed service intervals.

Table 2 | Rolls-Royce Civil Aerospace Annual Revenue 2015 to 2018 (H1)

\begin{tabular}{|c|c|c|c|c|c|c|c|c|c|c|}
\hline \multirow{2}{*}{$\begin{array}{l}\text { M-GDP } \\
\text { Engines }\end{array}$} & \multicolumn{2}{|c|}{2015} & \multicolumn{2}{|c|}{2016} & \multicolumn{2}{|c|}{2017} & \multicolumn{2}{|c|}{$2017-6$ months } & \multicolumn{2}{|c|}{$2018-6$ months } \\
\hline & $3,258.0$ & $47.0 \%$ & $3,357.0$ & $47.5 \%$ & $3,818.0$ & $47.6 \%$ & $2,594.0$ & $46.2 \%$ & $3,247.0$ & $48.6 \%$ \\
\hline Services & $3,675.0$ & $53.0 \%$ & $3,710.0$ & $52.5 \%$ & $4,205.0$ & $52.4 \%$ & $3,017.0$ & $53.8 \%$ & $3,433.0$ & $51.4 \%$ \\
\hline $\begin{array}{l}\text { Rolls-Royce } \\
\text { Total }\end{array}$ & $6,933.0$ & $100.0 \%$ & $7,067.0$ & $100.0 \%$ & $8,023.0$ & $100.0 \%$ & $5,611.0$ & $100.0 \%$ & $6,680.0$ & $100.0 \%$ \\
\hline $\begin{array}{l}\text { Operating } \\
\text { Profit }\end{array}$ & 812.0 & $11.7 \%$ & 367.0 & $5.2 \%$ & 520.0 & $6.5 \%$ & -250.0 & $-4.5 \%$ & -112.0 & $-1.7 \%$ \\
\hline \multicolumn{11}{|l|}{ Services } \\
\hline - LTSA & & & & & & & $1,455.0$ & $48.2 \%$ & $1,659.0$ & $-48.3 \%$ \\
\hline - Others & & & & & & & $1,562.0$ & $51.8 \%$ & $1,774.0$ & $51.7 \%$ \\
\hline $\begin{array}{l}\text { Services } \\
\text { Total }\end{array}$ & & & & & & & $3,017.0$ & $100.0 \%$ & $3,433.0$ & $100.0 \%$ \\
\hline LTSA/Total Revenue & & & & & & & $25.9 \%$ & & $24.8 \%$ & \\
\hline LTSA: Long-term Serv & ce Agree & & & & & & & & & \\
\hline
\end{tabular}

Sources: Rolls-Royce Annual Reports (2016, 2017, 2018 and H1 Reports 2017 \& 2018)

Since the late 90s, Rolls Royce has added their TotalCare program, which is more comprehensive, but still a Preventive Maintenance model.

As shown in Table 2, services today account for more than $50 \%$ of the total revenue, putting Rolls-Royce Civil Aerospace into Gebauer's (2006) $11 \%$ category of companies with more than $40 \%$ of their revenue derived from services.

Rolls-Royce is adjusting to the airlines' shift in strategic focus from owning and operating airplanes to transporting passengers as cost efficiently and reliably as possible.

This shift in strategic focus has put a significant pressure on the providers of MRO services, including Rolls-Royce Civil Aerospace.

Thanks to Big Data, Al and digital twins, Rolls Royce is now able to meet the clock speed requirements of the airlines to provide the necessary and individualized service on the respective jet engines (Rolls-Royce, 2017).

The digital technologies have enabled Rolls-Royce to align the customers' needs with their own capabilities and to expand its services from preventive to predictive maintenance.

Rolls-Royce has therefore re-organized its service into 24/7/365 operations and is collaborating with Microsoft regarding use of the Azure solutions to "embrace the cloud and 
analytical technologies to deliver more expert insights to the right stakeholders at the right time", Nick Farrant, Senior Vice President, Rolls-Royce ${ }^{5}$.

With the new Airline Aircraft Availability Center in the United Kingdom Rolls-Royce will be able to monitor the performance of the jet engines in real-time and in flight (Rolls-Royce, 2017) and proactively advice the service ground crew in their 74 authorized service centers on any repairs upon the aircraft's arrival.

According to Rolls-Royce, the TotalCare Program, i.e. the fact that Rolls-Royce is servicing the jet engines themselves, has the added benefit that it extends the service intervals by $25 \%$. The accumulation of large volumes of data (Big Data) on the performance of the engines and using Al will enable Rolls-Royce to offer predictive maintenance services and to reduce any unforeseen downtime ${ }^{7}$.

As customers only pay a fixed amount per flying hour, Rolls-Royce's TotalCare program offers the customers a full predictability of the operational costs during the ownership (Rolls-Royce, 2018). This is also in line with Mathieu's (2001) analysis of companies transitioning from offering services that support the products (SSP) to services supporting the clients (SSC), in this case the airline companies.

To quote Tom Palmer, Senior Vice President Services - Civil Aerospace, Rolls-Royce, "We will set up a complete line-service provision capability. To do this for customers all over the world we need to create a fast and efficient global distribution network for spare parts. The efficiency of the line-care programme will depend on us having the right people and the right equipment, in the right place, at the right time"8.

For Rolls-Royce, the LTSAs (Long-Term Service Agreements), which accounts for app. $50 \%$ of the total service revenue (see Table 2), offer not only a predictable long-term positive cash-flow, but also the potential to structure the service organization in a more optimal way.

Add that the life expectancy of a commercial aircraft is on average 25 years and 35 years for freighters (Jiang, 2013) and that air travel is expected to grow by five percent p.a. for the next 20 years and there is an interesting growth forecast for services.

In the case of Rolls-Royce, the revenue potential for services is evident.

It also means that Rolls-Royce is taking responsibility for the reliability and performance of the jet engines and is thereby part of the responsibility for the aircrafts' punctual departure and arrival, as indicated by Rolls-Royce' “On Time Every Time” slogan (Rolls Royce, 2017).

However, and as pointed out by Ambroise (2018), such a TotalCare program transfers the risk of ownership back to the manufacturer.

This can be costly if a machinery fails after the warranty period has expired. In Rolls-Royce' case a specific engine model with design defaults will for the period 2016-2022 be costing

\footnotetext{
${ }^{5}$ https://customers.microsoft.com/en-us/story/rollsroycestory, August 10, 2016

6 https://www.rolls-royce.com/media/our-stories/discover/2017/totalcare.aspx.

7 https://www.rolls-royce.com/media/our-stories/discover/2017/totalcare.aspx.

8 https://www.rolls-royce.com/media/our-stories/insights/2016/tom-palmer-on-data-driven-aviation.aspx.
} 
the company M-GBP 1,385 in additional maintenance and repairs (Rolls-Royce, 2018), which cannot be charged to the customers with a TotalCare LTSA.

These incurred costs also have a significant impact on the profit margins. As indicated in Table 2, the operational profit margin has fallen from $11.7 \%$ in 2015 to $6.5 \%$ in 2017 (the first six months of 2018 have even been negative).

\subsection{ABB - A Company Example}

The Swedish/Swiss ABB with a revenue of some M-EUR 28,133 annually is an industrial conglomerate and is, similar to Voith and Rolls-Royce (albeit for different applications), offering machinery and equipment solutions to the manufacturing industry, the power generation sectors and the transportation sector.

Despite ABB's strong strategic focus on IloT and AI (ABB, 2018), services account for a much smaller percentage (18\%) of total revenue than Rolls-Royce with more than $52 \%$ and Voith with almost 32\%. However, ABB has a higher profit margin, see Table 3 on page 10.

ABB is acknowledging that the digital transformation will have an impact on not only the competitiveness and employment within their own organization, but also those of their customers (ABB, 2017).

ABB is using the digital transformation to optimize their customers' operations.

ABB Ability was launched in 2017 to offer its customers a digital solution linking equipment and devices together and deliver the following advanced services predominantly to their industrial customers and relating to the ABB machinery and equipment (ABB, 2017),

- Performance optimization

- Asset health

- Condition monitoring

- Energy optimization

- Cyber security

To streamline the company and focus more on the automation, robotics and digital transformation areas ${ }^{9}$, ABB in December 2018 announced that the company would sell its power grid division, which in 2017 accounted for $29 \%$ of total annual revenue, or M-EUR 8,159 .

Acknowledging the need for agility in the digital transformation and to react faster to the customer needs, ABB at the same time announced that the company would streamline the organization and abolish their matrix organization ${ }^{10}$.

${ }^{9}$ https://www.ft.com/content/e100c94a-fdf9-11e8-ac00-57a2a826423e

10 https://new.abb.com/news/detail/12473/abb-shaping-a-leader-focused-in-digital-industries 
Table 3 | ABB Annual Revenue 2015 to 2018 (Q1-Q3)

\begin{tabular}{|c|c|c|c|c|c|c|c|c|c|c|}
\hline \multirow{2}{*}{$\begin{array}{l}\text { M-USD } \\
\text { Products }\end{array}$} & \multicolumn{2}{|c|}{2015} & \multicolumn{2}{|c|}{2016} & \multicolumn{2}{|c|}{2017} & \multicolumn{2}{|c|}{$2017-9$ months } & \multicolumn{2}{|c|}{2018 - 9 months } \\
\hline & 29,477 & $83.1 \%$ & 27,816 & $82.2 \%$ & 28,133 & $82.0 \%$ & 20,686 & $82.6 \%$ & 21,772 & $81.3 \%$ \\
\hline Services & 6,004 & $16.9 \%$ & 6,012 & $17.8 \%$ & 6,179 & $18.0 \%$ & 4,346 & $17.4 \%$ & 5,001 & $18.7 \%$ \\
\hline ABB Total & 35,481 & $100.0 \%$ & 33,828 & $100.0 \%$ & 34,312 & $100.0 \%$ & 25,032 & $100.0 \%$ & 26,773 & $100.0 \%$ \\
\hline EBITA & 4,209 & $11.9 \%$ & 4,191 & $12.4 \%$ & 4,130 & $12.0 \%$ & 3,109 & $12.4 \%$ & 3,345 & $12.5 \%$ \\
\hline
\end{tabular}

Sources: ABB Annual Reports (2016, 2017 and 2018 Q3 Report)

\subsection{Triple Challenge}

As the requirements for sensor based IoT, Big Data and Al solutions become more prominent, the risk amplifies that the ME companies will be pushed up the value chain, i.e. further away from the customers, by third party entrants, like Voith Digital Solutions.

These third-party service providers will have the potential to gain access to platform-based data (Predix, Mindsphere) and analytics to provide better, faster, cheaper and additional services.

For the latecomers in the machine and equipment manufacturing, the digitalization of the customer interactions is therefore an existential threat.

Thus, certain ME companies may be reduced to being OEM suppliers of machinery and spare-parts, competing on only quality, features and price, rather than margin generating solutions.

According to OECD (2017), these digital technologies and new processes will not only redefine the competitiveness of manufacturing companies, including new organizational models and needs of new skill-sets, but also significantly create and destroy jobs.

In addition, the more traditional (not born digital) companies will be faced with major challenges to embrace these digital technologies and new processes in a timely manner.

To preserve both sales and profitability many industrial companies will therefore be facing the triple challenge of

- Fending off traditional types of competitors from possibly new Asian countries,

- Facing new data analytics-based service providers and

- $\quad$ Being confronted with the conundrum of merging/morphing an industrial mind-set with the agility of the digital natives.

Machining and equipment manufacturing companies should be aware that larger machine manufacturers will be looking for opportunities to provide full services, also on the full production lines, including third party equipment, as stated both by Voith (2016) and GE.

It's worth noting that exactly General Electric (GE) itself has been hit by this triple challenge. 
Lately, GE Digital has been forced to scale back its ambitions (reducing the annual budget by $25 \%$, or M-USD 400 ) of making Predix an "all-purpose software for the wider industrial world" (Lohr, 2018).

Internally, GE has realized the challenge of merging the mind-set of producing big equipment for aviation, energy or medical purposes with the mind-set of Silicon Valley digital natives and so far, only $8 \%$ of GE's industrial customers are presently using Predix ${ }^{11}$.

In the meantime, GE is experiencing strong competition from

- $\quad$ Traditional competitors like ABB and Siemens. Siemens' Mindsphere platform is also Predix' biggest competitor.

- Digital competition from companies like Microsoft (with the Azure Cloud platform), Amazon (with cloud-based Amazon Web Services) and Google offering cloud solutions, SAP, IBM and Oracle offering software solutions.

- $\quad$ New market entrants like C3loT ${ }^{12}$, which has recently been selected as a partner to assist $3 \mathrm{M}$ in its implementation of its digital transformation ${ }^{13}$.

Against previous expectations, GE Digital with its Predix platform realized a $2 \%$ drop in sales and was forced to reduce its staff ${ }^{14}$. According to leading US business journals ${ }^{1516}$, the main reason for GE Digital's problems was not the market, but rather internal issues such as short-term focus, quality issues of software and a general problem of transforming an industrial company from an industrial mindset to a software driven service provider.

The triple challenge for machining companies can be exemplified by Volkswagen's recent announcement that the company and "Amazon Web Services (AWS) are to develop the Volkswagen Industrial Cloud together"17 in order to lay the foundation for the seamless digitalization of its production and logistics and to develop a new Digital Production Platform (DPP). For the industrial and machining companies supplying the Volkswagen Group this initiative means that they will be invited to share their data on the platform in a standardized way. Ultimately this could also mean that these suppliers are no longer owners of their own data and would possibly need to compete for maintenance contracts on their own equipment.

It therefore becomes clear that industrial companies will need to work in multiple directions to be able to deliver revenue and profit generating Product Service Systems (PSS).

\footnotetext{
${ }^{11}$ https://www.nytimes.com/2018/04/19/business/ge-digital-ambitions. html

12 C3loT and Microsoft have recently announced a strategic partnership to develop and provide Al based solutions.

${ }^{13} \mathrm{https}: / /$ news.microsoft.com/2018/04/10/c3-iot-and-microsoft-announce-strategic-partnership-to-accelerate-ai-in-theenterprise/

${ }^{14}$ https://www.crn.com/news/internet-of-things/ge-digital-layoffs-driven-by-commercial-demands-not-spin-off-plans

15 https://www.forbes.com/sites/blakemorgan/2019/09/30/companies-that-failed-at-digital-transformation-and-what-wecan-learn-from-them/\#1ab4fff3603c

${ }^{16}$ https://www.nytimes.com/2018/04/19/business/ge-digital-ambitions.htm/

17 https://www.volkswagenag.com/en/news/2019/03/volkswagen-and-amazon-web-services-to-develop-industrialcloud.html
} 


\section{Implications for Industrial Companies}

Combining the findings from ABB, Rolls-Royce and Voith it is possible to build a rather compelling business case for new services and to provide recommendations for the ME companies entering into advanced services.

\subsection{New Service and Revenue Models - A Hypothesis}

What would it be worth, if a traditional equipment company, say one of the four largest global suppliers of lifts and escalators, Kone (FIN), Otis (USA), Schindler (CH) and ThyssenKrupp (D), could monetize the movement of people and what would it mean to the existing business model?

Till date, all four companies are running a fairly traditional business, selling, installing and maintaining lifts, escalators and moving walkways even though the Finnish Kone and IBM have announced a collaboration in the era of IoT, using IBM's Watson for predictive maintenance of lifts (Slowey, 2017).

The purpose of using Watson is to tailor-make and schedule needed services for each individual lift from Kone, rather than the more traditional fixed-interval service contracts.

The use of Watson will, according to IBM, also provide Kone with the possibility to provide new services such as people flow in buildings and smart building applications.

Kone (2018) still sees itself as a manufacturer and supplier of equipment and related services. According to the same annual report, new equipment is $53 \%$ of the total revenue, whereas maintenance and modernization/refurbishment account for are 32\% and 14\% respectively of total revenue (the missing one percent is due to rounding).

In the annual report, new services are not measurable.

According to the Swiss company Schindler's Annual Report 2013, the company moves one billion (1.000.000.000) people every day with its equipment.

With an annual revenue of M-EUR 8,942 Kone (2018) is approximately the same size as Schindler (2018) with an annual revenue of M-CHF 10,179). Thus, it can be assumed that Kone is also moving approximately one billion people a day.

Using the new digital technologies and processes, especially AI (Artificial Intelligence) on connected lifts and escalators, what could the business model look like if it would be possible to monetize a fraction of this people flow?

As described by Farahat (2013), traditional (online) advertising has become a much less efficient way, as measured by clickthrough rates (CTR) to market and sell products and services.

Advertisers' response has been to target the advertising according to the viewers'/customers' personal demographic characteristics and preferences (browsing history, IP addresses, social media profiles, shopping history, etc.).

Analyzing 332 million unique visits to Yahoo and the impact of 18 advertising campaigns on their front-page during a four-month period, separating non-targeted from targeted visitors, 
segmented into specific Behavioral Targeting (BT) categories Farahat was able to identify their behavior and reactions to specific advertisements.

Accounting for different selection bias and overlaps between the BT categories, Farahat was able to identify a significant increase in brand related interest among the targeted groups. In other words, targeted viewers will react more strongly (by clicks) to front-page advertising of their preferred brands.

Using Farahat's findings in an IloT and Al setting, a rather interesting business model arises around the daily people flow on escalators and in lifts.

Using Zurich Airport as a business case, it is possible to calculate a potential revenue stream for advertising towards a targeted customer group based on the following assumptions:

Table 4 | Assumptions

\begin{tabular}{ll} 
Advertiser & A car brand \\
Target Group & Business traveller \\
Age Groups & $26-44$ \\
& $45-64$ \\
Travel Specifics & Arriving to the airport by car \\
& Departing from Terminal A \\
\hline
\end{tabular}

Source: Author

Terminal A predominantly handles airlines belonging to the Lufthansa Group (Lufthansa, Swiss, Edelweiss, Austrian airlines).

Additional assumptions:

1) The percentages (marked in bold) in Table 5 also pertain to the business travellers.

2) Car brands and models can be identified through the existing surveillance cameras upon entry into the parking.

3) The driver's age can be estimated using facial recognition

4) The lifts are equipped with interactive mirrors ${ }^{18}$

5) The lifts and the cameras are connected into an IloT network and the data is analysed and processed real-time

6) The advertising value of being able to segment an individual passenger is app. EUR 0.50 , according to an industry specialist. As a reference point, the average Cost-perClick (CPC) for advertisers on a webpage is USD 0.75 in Switzerland ${ }^{19}$.

${ }^{18}$ https://elevatortoday.com/2018/01/18/magic-mirror-for-elevators/

${ }^{19}$ https://adespresso.com/blog/facebook-ads-cost/ 
Data Zurich Airport 2017

\begin{tabular}{|c|c|c|c|c|}
\hline (x) & & & Total & Terminal A \\
\hline Passengers annually & & 29,396,094 & & \\
\hline Passengers daily average & & 80,537 & & \\
\hline Local passengers daily average & $71.6 \%$ & 57,644 & & \\
\hline Passengers departing from Terminal $\mathbf{A}$ & $45.5 \%$ & 36,644 & & \\
\hline Local passengers departing from Terminal A & $45.5 \%$ & 26,237 & & \\
\hline Business passengers & $31.0 \%$ & 24,966 & & \\
\hline Departing local business passengers & $31.0 \%$ & & 17,876 & 8,134 \\
\hline Age $26-44$ & $44.0 \%$ & & 7,865 & 3,579 \\
\hline Age $45-64$ & $33.0 \%$ & & 5,899 & 2,684 \\
\hline Passengers w. dwell time $61-90$ minutes & $31.0 \%$ & & 5,542 & \\
\hline Passengers w. dwell time above 90 minutes & $49.0 \%$ & & 8,759 & \\
\hline Passengers arriving w private transportation & $39.0 \%$ & & 6,972 & 3,172 \\
\hline Number of park spaces in park house $1 \& 2$ & & 5,000 & & \\
\hline Number of escalators & & 93 & & \\
\hline Number of lifts & & 194 & & \\
\hline
\end{tabular}

Source: Facts and figures Zurich Airport (2017)

According to the figures in Table 5, 3,172 or $17.7 \%$ of all daily business travelers will arrive by car and depart from Terminal $A$.

Triangulating time, place and car models and combining this with machine learning (Al), it should be relatively straightforward to present semi tailor-made commercials to the lift users aka the business travelers.

Assuming that this commercial would have a value of EUR 0.10 per lift user, paid for by the advertiser. The annual revenue from tailor-made advertising towards 3,172 daily business travelers amounts to:

\section{$3,172 \times 0.10 \times 365=$ EUR 115,778 per year}

The advertising revenue will be significantly higher, if tailored and dynamic advertising can be placed on the escalators throughout the airport, using Al to identify the business travelers.

Though the lift and escalator manufacturers presently concentrate their efforts on using llot and Al to improve their servitization models, the simple example from Zurich Airport gives a glimpse of the revenue potential from using the digital technologies in other ways. 
Assuming that it would be possible in a similar fashion to target $5 \%$ of all daily users of lifts and escalators, globally, using the 2018 EBIT margin of $25.60 \%$ from Google's parent company Alphabet ${ }^{20}$ as a data driven company, the real and hypothetical annual revenue and EBIT numbers would look like the following:

Revenue: $1,000,000,000 \times 5 \% \times 0.50$ EUR $\times 365=$ M-EUR 9,100

EBIT: M-EUR 9,100 x 25.60\% = M-EUR 2,329.6

For Kone the hypothetical 2018 figures for the new advertising services would then look like the following example (Table 6).

Table 6 | Kone

\begin{tabular}{|c|c|c|c|c|c|c|c|c|c|}
\hline \multirow{2}{*}{$\begin{array}{l}\text { M-EUR } \\
\text { New Equipment }\end{array}$} & \multicolumn{2}{|c|}{2015} & \multicolumn{2}{|c|}{2016} & \multicolumn{2}{|c|}{2017} & \multicolumn{2}{|c|}{2018} & \multirow{2}{*}{$\begin{array}{r}\text { Period } \\
-2.8 \%\end{array}$} \\
\hline & $4,935.0$ & $57.1 \%$ & $4,793.0$ & $54.6 \%$ & $4,654.0$ & $52.9 \%$ & $4,797.0$ & $52.9 \%$ & \\
\hline Modernization & $1,071.0$ & $12.4 \%$ & $1,219.0$ & $13.9 \%$ & $1,256.0$ & $14.3 \%$ & $1,305.0$ & $14.4 \%$ & $21.8 \%$ \\
\hline Services & $2,642.0$ & $30,6 \%$ & $2,773.0$ & $31.6 \%$ & $2,887.0$ & $32.8 \%$ & $2,969.0$ & $32.7 \%$ & $12.4 \%$ \\
\hline Total Revenue & $8,648.0$ & $100.0 \%$ & $8,785.0$ & $100.0 \%$ & $8,797.0$ & $100.0 \%$ & $9,071.0$ & $100.0 \%$ & $4.9 \%$ \\
\hline \multicolumn{10}{|l|}{ Potential } \\
\hline \multicolumn{10}{|l|}{ Advertising Revenue } \\
\hline Potential Total Revenue & & & & & & & $18,171.0$ & & \\
\hline EBIT & $1,241.5$ & $14.4 \%$ & $1,293.3$ & $14.7 \%$ & $1,192.3$ & $13.6 \%$ & $1,042.4$ & $11.5 \%$ & $-16.0 \%$ \\
\hline \multicolumn{10}{|l|}{ Potential } \\
\hline Advertising EBIT & & & & & & & $2,329.6$ & $25.6 \%$ & \\
\hline Potential Total EBIT & & & & & & & $3,372.0$ & $18.6 \%$ & \\
\hline
\end{tabular}

Sources: Kone Annual Review (2016, 2017, 2018)

The big question is what it would mean to Kone's business model, if more than $69 \%$ of the EBIT margin would be derived from a completely different source than usual.

Would a classical equipment manufacturing, and service company be able to embrace an additional line of business called "Al driven and consumer targeted advertising"?

Fact is that a data driven (advertising) company like Alphabet has more than twice as high an EBIT margin as Kone, which, as an equipment and service provider, according to Fischer (2012) is already at the higher end compared to other companies of similar type.

The combination of $\mathrm{Al}$ and B2B equipment opens up new business opportunities and the revenue potential can be significant.

But, to reap these benefits, the strategic decision must be taken, the right organizational structure must be in place and the needed investments undertaken.

As indicated in Table 7 on page 67, the digital transformation can enable industrial companies to add more advanced services to their offerings and to integrate themselves deeper into the value chain of their customers.

${ }^{20}$ https://www.stock-analysis-on.net/NASDAQ/Company/Alphabet-Inc/Valuation/EV-to-EBITDA 
However, and as stated by Ambroise (2018), Benedettini (2015) and Lay (2014), a successful and profitable servitization strategy depends on a combination of mind-set, leadership, organization and a correct understanding of the company's own value proposition and market justification.

\section{Table 7 | Product Service Systems Applying Digital Technologies}

\begin{tabular}{|c|c|c|c|c|c|c|c|}
\hline \multicolumn{2}{|c|}{$\begin{array}{l}\text { Machinery \& } \\
\text { Equipment Components }\end{array}$} & \multirow{2}{*}{$\begin{array}{l}\frac{\text { o }}{\mathrm{T}} \\
\frac{\mathrm{c}}{4} \\
\mathrm{x}\end{array}$} & \multirow{2}{*}{$\stackrel{\stackrel{\vdash}{=}}{\mathrm{x}}$} & \multirow{2}{*}{$\frac{\bar{\alpha}}{x}$} & \multirow[t]{2}{*}{$\begin{array}{c}\text { Examples } \\
\text { Applications/Topics/Services }\end{array}$} & \multirow{2}{*}{$\begin{array}{c}\text { Examples } \\
\text { Companies } \\
\text { ABB }\end{array}$} & \multirow{2}{*}{$\begin{array}{c}\begin{array}{c}\text { Revenue } \\
\text { Models }\end{array} \\
\text { Sales of products }\end{array}$} \\
\hline \multirow{7}{*}{ 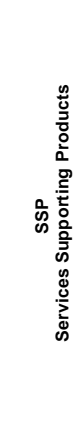 } & Spare parts & & & & & & \\
\hline & $\begin{array}{l}\text { Unscheduled } \\
\text { Service }\end{array}$ & $\mathrm{x}$ & $\mathrm{x}$ & & & Voith & $\begin{array}{l}\text { Sales of hours } \\
\text { and parts }\end{array}$ \\
\hline & $\begin{array}{l}\text { Preventive Maintenance } \\
\text { - Uptime }\end{array}$ & $\mathrm{x}$ & $\mathrm{x}$ & $\mathrm{x}$ & $\begin{array}{l}\text { Power-by-the-Hour by } \\
\text { Rolls Royce (since 1962) }\end{array}$ & Rolls Royce & $\begin{array}{l}\text { Service } \\
\text { contracts }\end{array}$ \\
\hline & $\begin{array}{l}\text { Customer service } \\
\text { - Information }\end{array}$ & $\mathrm{x}$ & & & & & \multirow{4}{*}{$\begin{array}{l}\text { Included in machine/ } \\
\text { equipment } \\
\text { price }\end{array}$} \\
\hline & $\begin{array}{l}\text { - Delivery } \\
\text { - Billing }\end{array}$ & $x$ & & & & & \\
\hline & - Documentation & $x$ & & & & & \\
\hline & - Equipment training & $\mathrm{x}$ & & & & & \\
\hline \multirow{10}{*}{ 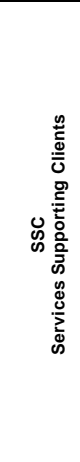 } & Engineering services & $\mathrm{x}$ & $\mathrm{x}$ & $\mathrm{x}$ & Operational building management & $\begin{array}{l}\text { Johnson Controls/ } \\
\text { Tyco }\end{array}$ & $\begin{array}{l}\text { Maintenance } \\
\text { contracts }\end{array}$ \\
\hline & Predictive maintenance & & $x$ & $x$ & Digital twins & GE, Rolls Royce & \multirow{3}{*}{$\begin{array}{l}\text { Performance based } \\
\text { contracts }\end{array}$} \\
\hline & - Uptime & & $\mathrm{x}$ & $\mathrm{x}$ & Real time service & Rolls Royce & \\
\hline & - Full production lines & & $\mathrm{x}$ & $\mathrm{x}$ & Service of competitors' products & Voith, GE & \\
\hline & $\begin{array}{l}\text { Performance based } \\
\text { services }\end{array}$ & & $\mathrm{x}$ & $\mathrm{x}$ & \multirow{5}{*}{$\begin{array}{c}\text { Volume, cooling and quality } \\
\text { monitoring in plastic injection } \\
\text { moulding } \\
\text { Energy and material savings } \\
\text { Book printing } \\
\text { (Minimum volume of one) }\end{array}$} & & \multirow{5}{*}{$\begin{array}{c}\text { Performance based } \\
\text { contracts } \\
\text { Output based } \\
\text { payments }\end{array}$} \\
\hline & - Throughput & & $\mathrm{x}$ & $x$ & & & \\
\hline & - Consistency & & $\mathrm{x}$ & $\mathrm{x}$ & & & \\
\hline & - Quality & & $x$ & $\mathrm{x}$ & & & \\
\hline & - Econometrics & & & $\mathrm{x}$ & & & \\
\hline & $\begin{array}{l}\text { Complex project planning \& } \\
\text { systems design }\end{array}$ & & & $\mathrm{x}$ & $\begin{array}{l}\text { Data-based design and production } \\
\text { scenarios }\end{array}$ & & Fee based \\
\hline \multirow{7}{*}{ 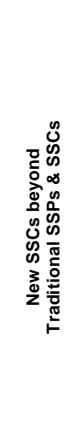 } & Training programmes & & & $x$ & $\begin{array}{l}\text { Pilot monitoring and training based on } \\
\text { Big Data inputs }\end{array}$ & Rolls Royce & Fee based \\
\hline & Quality certification & & & $\mathrm{x}$ & $\begin{array}{l}\text { Communication w. consumers and } \\
\text { authorities }\end{array}$ & $\begin{array}{l}\text { Food processing } \\
\text { machine manufact. }\end{array}$ & Fee based \\
\hline & Production optimisation & & & $x$ & $\begin{array}{l}\text { Recommendation and guidance for } \\
\text { sowing and harvesting }\end{array}$ & John Deere & Subscription \\
\hline & $\begin{array}{l}\text { Machinery \& equipment } \\
\text { handling }\end{array}$ & & & $\mathrm{x}$ & $\begin{array}{l}\text { Monitoring and improving driving } \\
\text { performance of lorries }\end{array}$ & $\begin{array}{l}\text { Scandia } \\
\text { Continental }\end{array}$ & Subscription \\
\hline & $\begin{array}{l}\text { Monitoring \& security } \\
\text { systems }\end{array}$ & & & $\mathrm{x}$ & $\begin{array}{l}\text { People mobility monitoring and } \\
\text { management }\end{array}$ & $\begin{array}{l}\text { Manufacturers of lifts } \\
\& \text { escalators }\end{array}$ & Subscription \\
\hline & $\begin{array}{l}\text { Targeted consumer } \\
\text { information }\end{array}$ & & & $\mathrm{x}$ & B-2-C advertising & $\begin{array}{l}\text { Manufacturers of lifts } \\
\& \text { escalators }\end{array}$ & Fee based \\
\hline & Power-by-the-Hour & & & $x$ & From jet engine to thrust & GE consideration & Pay-per-use \\
\hline
\end{tabular}

Source: Author's composition. Additional sources: OECD (2017), Lay (2014), Fischer (2012) 


\subsection{Re-adjustment or Re-definition of Strategy and Market Justification}

Circling back to Levitt (1960), the leadership of industrial companies should re-visit their existing Unique Selling Proposition (USP) in the eyes of their present and potentially new customers. This re-evaluation invariably leads to the discussion of whether the industrial company is producing machines or supplying solutions and whether the services provided support the products (SSPs) or support the customers (SSCs).

Only then is it possible to discuss the strategic positioning, the impact of digital technologies and new processes, the organizational requirements and the financial implications.

As indicated by Voith (2018) the concept of expanding services beyond their core products (machinery, equipment) is not hampered by technologies, or on-site availability, but rather by traditional (vertical) organizational structures, including the traditional service organizations - and mind-set.

As explained by Wade (2015) and exemplified by the steps taken by companies such as Rolls-Royce and Voith, a fundamental challenge is to adapt to this new business environment of selling performance and to structure the organization such that the customer needs can be translated into the right mix of machines, services and payment schemes (thus doing the proper profitability calculations).

\subsection{Dealing with Six Issues to Implement Service Models Successfully}

To implement new service models successfully, the following six issues should be considered.

First, industrial ME companies will need to decide, if services serve the purpose of only customer retention, i.e. defence of existing market and value position, or also market expansion, i.e. the capture of new and hitherto untapped/unknown services.

These considerations are in line with the general discussion dealing with the question if the company sees itself as predominantly a machine manufacturer, or as an enabling service provider assisting its customers to produce and deliver their products.

Second, and as presented schematically in Table 7, the companies will need to decide if their services will continue only to support the products (SSP). Or the companies have the capacity to expand the service portfolio to include more customer-oriented services (SSC), be it engineering services, guaranteeing uptime through predictive maintenance, or possibly integrating themselves in the production processes by offering performance-based services, or complex engineering \& design solutions.

Third, and the core of this paper, the ME companies need to decide on the level of digitalization they are willing and able to implement to offer these services.

The SSP offerings can in all likelihood continue in the analogue world until the customers may demand IoT based solutions, or the competition forces the MEs to catch up to retain the customers. 
Fourth, and dependent on the answer to question three, embracing $\mathrm{Al}$ and machine learning open up the possibility to offer new customer-oriented services (SSCs) as indicated in Table 7.

The MEs can, with the combination of IoT and AI, turn the Big Data from customers and uses of their machines and equipment into new and valuable services. These technologies and processes open up the possibility to communicate directly with end consumers i.e. the customers of the products being produced on the machines supplied by the ME companies.

Together with the customers, it is possible to offer new (and profitable) services to the B2B2C market. In Table 7 are listed examples like training programs for pilots or truck drivers, quality certification of foods, or direct advertising and mobility management systems.

The possibility to communicate directly with the end consumers can also serve the purpose of strengthening or defending a market position.

A classic example is the "Intel Inside" strategy from the 1990s where Intel defended its B2B market position by turning a hitherto to the consumer unknown computer chip into a household brand, and thereby adding pressure onto the computer manufacturers to install the Intel chips into the computers.

Zimmermann (2010) argues that this radical marketing approach was only possible in a large organization like Intel due to Corporate Entrepreneurship, fostering a rebellious and chaotic internal culture supported by the management.

Fifth, the ME companies will need to develop pricing models which reflect the financial value of the services offered to the customers, like uptime, performance and quality. The connectivity of the machines also offers a possibility to "lock-in" the customers, i.e. making it more difficult to substitute the ME supplier, as discussed by Porter (2014).

Pricing models can generally be fee based or performance based. The performance-based pricing models require a very high degree of confidence in the machines/equipment supplied and a close collaboration with the customers to ensure its proper use. Otherwise the pricing/profit model can easily turn into a loss-making business with possibly detrimental consequences.

In addition, predictive maintenance may actually reduce the service income on the individual customers. As the service becomes predictive, repairs on machines with breakdowns are becoming more seldom and customers may demand that the service contracts are revised downwards accordingly.

Sixth, entering into data driven loT service solutions, however, may require not only new digital experts, but also a modification of mind-set among the existing staff to understand and support the need for digitalization.

The digitalization will therefore most likely impact almost all of the steps in the ME companies internal value chain, be it for internal efficiency optimization reasons, or as mentioned due to market pressures.

The "clashes" between the classical machine manufacture mind-set, the mind-set of a service-driven entity and the thinking of digital natives should not be underestimated. 
These personnel groups literally speak completely different languages and it is the responsibility of management to bring these groups onto a common denominator in terms of providing valuable solutions for existing and new customers.

In addition, there is a shortage of Al experts and the ones available are expensive, with salaries approaching USD 300.000 for newly graduated $\mathrm{PhDs}^{21}$. Ways of bridging the digital divide are to look for strategic co-operations with start-ups or to pool resources with other ME companies in related fields or the customers themselves. ${ }^{22}$

\subsection{New Business Models}

Deciding on these six different aspects requires a thorough dialogue with the key customers not only about requirements and deliverables, but also more fundamentally about both the MEs and the customers respective value proposition today and in the future.

Figure 1 below summarizes an ME company's linkage between the external forces of value proposition and market justification, the internal realities of the present strategy, organizational capabilities and financial strength, and the new enabling digital technologies. Combining the three distinct elements can guide an ME company towards developing new and profitable business models.

Figure 1 | Business Models

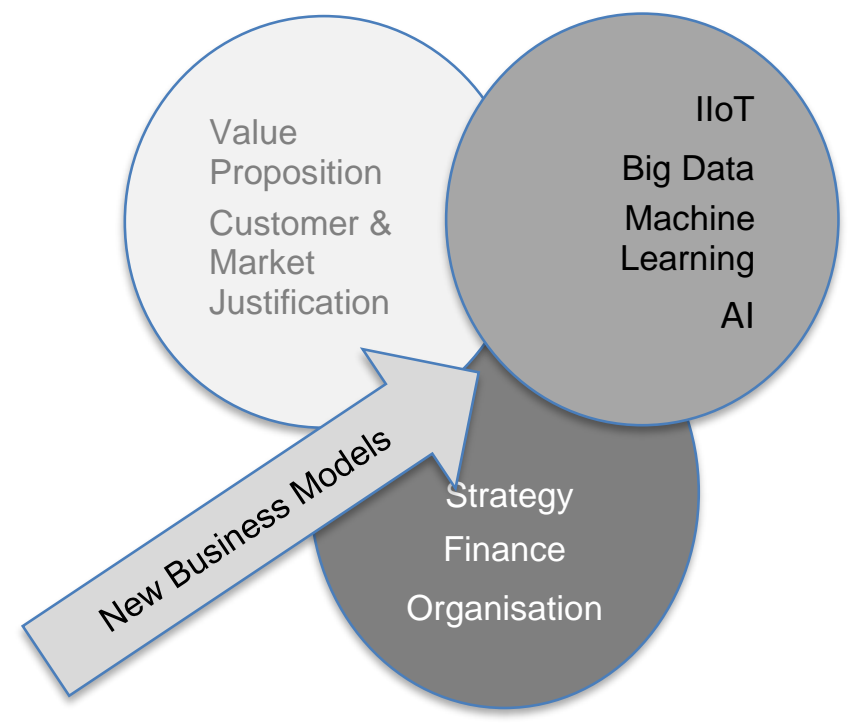

Source: Author's composition

To develop and successfully implement any new service/business models, the companies will therefore need to take a fresh look at their strategy, the financial implications, the market risks (of "business as usual") and what the organizational consequences could be.

${ }^{21}$ https://www.bloomberg.com/news/articles/2018-02-13/in-the-war-for-ai-talent-sky-high-salaries-are-the-weapons

22 This author is sitting on the board of an industrial company going through the similar digitalization business model considerations. Part of the solution has been to engage directly with ICT Master students from a reputed university. 


\subsection{Last Words}

The disruptiveness of the digital transformation will for some industrial companies be a threat leading to their demise. For other existing and new companies, the digital technologies, especially Big Data and Al, will be enablers to merge the best of what Europe has to offer: quality, know-how, service, distribution, market access in order to build new and profitable business models - moving deeper into services.

To paraphrase lan Roberts, CTO of the Swiss Bühler Group AG: the company owning the data and analytics owns the customer.

And Bill Ruh, GE Digital: "Industrial companies that don't invest in data now, will eventually be like consumer companies that missed the Internet: It's going to be too late. ${ }^{123}$

Thus, the question for an ME company is not to develop a digitalization strategy, but rather to consider how these technologies can enable the companies to continue to have a market justification - successfully.

And "therein lies the rub", as William Shakespeare wrote in Hamlet.

\section{Limitations and Further Research}

Industrial companies continued success not only depends on the right mix of value proposition, servitization strategy, organization and leadership, but also on fundamental competitive quality and therefore internal efficiency and agility.

The industrial companies who are embracing the digital transformation should therefore also be looking for ways to make better use of the wealth of data, accumulated during production to improve existing business processes, towards "intelligent" manufacturing systems and supply chains, before moving into new business areas.

The importance and potential impact on industrial companies of the Circular Economy should not be underestimated. In December 2019 the European Commission in a policy communication launched The European Green Deal ${ }^{24}$, among other presenting upcoming policy changes to "adopt an EU industrial strategy to address the twin challenge of the green and the digital transformation".

Re-manufacturing, the right to repair and products as services will be among the main topics in the coming years and will be reflected in the new Horizon Europe Research Programmes for 2021-2027, where "Digital, Industry and Space"25will be an important cluster.

IloT, Big Data and Al are also enablers for continuous optimization of internal processes and to become more agile. Linking agility and the above topics to advanced servitization strategies have not been covered by this paper.

Cybersecurity is an equally important topic that needs to be addressed.

${ }^{23}$ https://www.fastcompany.com/3031272/can-jeff-immelt-really-make-the-world-1-better

24 https://eur-lex.europa.eu/legal-content/EN/TXT/?qid=1576150542719\&uri=COM\%3A2019\%3A640\%3AFIN

25 https://ec.europa.eu/research/pdf/horizon-europe/annex-4.pdf 


\section{Acknowledgements}

This author is grateful for the discussions and inputs from industry experts and counselling on the academic angle of this paper.

A special thanks to the following people listed in alphabetical order:

- Dr. Chris Greer, Director of the Smart Grid and Cyber-Physical Systems Program Office, National Institute of Standards and Technologies (NIST).

- Prof. Dr. Jiří Hnilica, Head of Department of Strategy and Vice-Rector for International Relations and Information Systems, University of Economics, Prague.

- Dr. Grégoire Meylan, Senior Project Manager, Center for International Industrial Solutions, Zurich University of Applied Sciences.

- Dr. Nabil Nasr, Associate Provost and Director of the Golisano Institute for Sustainability, Rochester Institute of Technology.

- Dr. lan Roberts, CTO Bühler AG.

- Robert Rudolph, Member of the Executive Board, Swissmem.

- $\quad$ Prof. Dr. Daniel Seelhofer, Rector, East University of Applied Sciences.

- Dr. Mark Soley, Chairman of the Industrial Internet Consortium.

Big thanks also to the CEOs of leading industrial machinery and equipment manufacturers who shared their views and concerns regarding the challenges and opportunities with the ongoing digital transformation and who remain anonymous for confidentiality reasons.

\section{References}

ABB (2017). Positioned for Profitable Growth. Annual Report 2017. Retrieved February 07, 2019 from https://library.e.abb.com/public/7fbb3c078f10489c92a03eb5f3d89751/ABB-Group-Annual-

Report-2017-English.pdf?xsign=eoPSsrGdRkkYTK2Ob4VtbleW4t0PIKSd1VR8L+gaGBrSMHgffJd90r4AJu5LBQ6Z.

ABB (2018). ABB: Shaping a leader focused in digital industries. Press release December 17, 2018. Retrieved February 04, 2019 from https://www.writing-the-future.com/sites/default/files/201812/ABB Shaping a leader focused in digital industries.pdf.

Ambroise, L., Prim-Allaz, I., \& Teyssier, C. (2018). Financial performance of servitized manufacturing companies: A configuration issue between servitization strategies and customer oriented organizational design. Industrial Marketing Management, 71, 54-68. Retrieved January 21, 2019 from https://www.sciencedirect.com/science/article/abs/pii/S0019850117308441.

Antioco, M., Moenaert, R., Lindgreen, A., \& Wetzels, M. (2008). Organizational antecedents to and consequences of service business orientations in manufacturing companies. Journal of the Academy of Marketing Science, 36, 337-358. Retrieved January 24, 2019 from https://link.springer.com/content/pdf/10.1007\%2Fs11747-008-0085-1.pdf.

Baines, T.S., Lightfoot, H.W., Steve, E., Neely, A., Greenough, R., \& et al. (2007). State-of-the-art in product service-systems. Journal of Engineering Manufacture, 221, 1-10. Retrieved November 21, 2017 from https://doi.org/10.1243\%2F09544054JEM858.

Baines, T.S., Lightfoot, H.W., Benedetti, O., \& Kay, J.M. (2009). The servitization of manufacturing: A review of literature and reflection of future changes. Journal of Manufacturing Technology Management, 20(5), 547-567. Retrieved January 24, 2019 from https://doi.org/10.1108/17410380910960984. 
Baines, T., Ziaee Bigdeli, A., Bustinza, O.F., Shi, V.G., Baldwin, J. and Ridgway, K. (2017). Servitization: revisiting the state-of-the-art and research priorities. International Journal of Operations \& Production Management, 37(2), 256-278. Retrieved January 24, 2019 from https://doi.org/10.1108/lJOPM-06-2015-0312.

Baur, C., Wee, D. (2015). Manufacturing's next act. Retrieved June 24, 2015 from https://www.mckinsey.com/business-functions/operations/our-insights/manufacturings-next-act

Benedettini, O., Neely, A., \& Swink, M. (2015). Why Do Servitized Firms Fail? A Risk-Based Explanation. International Journal of Operations \& Production Management, 35(6), 946-979. Retrieved November 30, 2017 from https://doi.org/10.1108/IJOPM-02-2014-0052.

Benedettini, O., Swink, M., \& Neely, A. (2017). Examining the influence of service additions on manufacturing firms' bankruptcy likelihood. Industrial Marketing Management, 60, 112-125. Retrieved January 24, 2019 from https://doi.org/10.1016/j.indmarman.2016.04.011.

Bontis, N. (1999). Managing organizational knowledge by diagnosing intellectual capital: framing and advancing the state of the field. International Journal of Technology Management, 18(5-8), 433. Retrieved March 19, 2019 from https://www.researchgate.net/profile/Nick Bontis/publication/2400013.

Böhm, E., \& Eggert, A., Thiesbrummel, C. (2017). Service transition: A viable option for manufacturing companies with deteriorating financial performance? Industrial Marketing Management, 60, 101-111. Retrieved January 24, 2019 from https://doi.org/10.1016/j.indmarman.2016.04.007.

Crozet, M., \& Milet, E. (2015). The future of manufacturing lies in services. VOX CEPR Policy Portal. Retrieved July 27, 2016 from https://voxeu.org/article/future-manufacturing-lies-services

Davis, R. (2015). Industry 4.0 Digitalisation for productivity and growth. European Parliamentary Research Service. Retrieved January 29, 2019 from http://www.europarl.europa.eu/RegData/etudes/BRIE/2015/568337/EPRS BRI(2015)568337 EN.pdf.

Editorial, (2018). Learning the lessons of GE's steepening decline. Financial Times November 27, 2018. Retreived February 04, 2019 from https://www.ft.com/content/c8daf298-ef2e-11e8-81809cf212677a57.

European Commision (2016). Commission sets out path to digitise European industry. Press Release. Retrieved January 31, 2019 from http://europa.eu/rapid/press-release IP-16-1407 en.htm.

Evans, P., \& Annunziata, M. (2012). Industrial Internet: Pushing the Boundaries of Minds and $\begin{array}{lllll}\text { Machines. } & \text { Retrieved June } & 018 \text { from }\end{array}$ https://www.ge.com/docs/chapters/Industrial Internet.pdf

Farahat, A. (2013) How Effective is Targeted Advertising? 2013 American Control Conference (ACC). $\begin{array}{llll}\text { Retrieved January } & 3019 & \text { from }\end{array}$ https://ieeexplore.ieee.org/stamp/stamp.jsp?tp=\&arnumber=6580780.

Felipe, J., Mehta, A., \& Rhee, C. (2019). Manufacturing matters...but it's the jobs that count. Cambridge Journal of Economics, 43(1), 139-168. Retrieved January 21, 2019 from https://doi.org/10.1093/cje/bex086.

Fischer, T., Gebauer, H., \& Fleisch, E. (2012). Service Business Development. Strategies for Value Creation in Manufacturing Firms. Cambridge University Press.

Gallo, A. (2016). A Refresher on Marketing Myopia. Harvard Business Review 08. Retrieved February 06, 2019 from https://hbr.org/2016/08/a-refresher-on-marketing-myopia. 
Gebauer, H., Friedli, T., \& Fleisch, E. (2006). Success factors for achieving high services revenues in manufacturing companies. Benchmarking: An International Journal, 13(3), 374-386. Retrieved January 24, 2019 from https://doi.org/10.1093/cje/bex086.

Gebauer, H., Edvardsson, B., \& Bjurko, M. (2010). The impact of service orientation in corporate culture on business performance in manufacturing companies. Journal of Service Management, 21(2), 237-257. Retrieved January 24, 2019 from https://doi.org/10.1093/cje/bex086.

Gebauer, H., Saul, C.J., Haldimann, M., \& Gustafsson, A. (2017). Organizational capabilities for payper-use services in product-oriented companies. International Journal of Production Economics, 192, 157-168. Retrieved November 24, 2017 from https://www.sciencedirect.com/science/article/pii/S092552731630384X

Hakanen, T., Kansola, M., \& Valkokari, K. (2014) Acquiring Customer Knowledge to Enhance Servitization of Industrial Companies. Servitization in Industry, 191-209.

Herterich, M., Uebernickel, F., \& Brenner, W. (2015). The Impact of Cyber-Physical Systems on Industrial Services in Manufacturing. 7th Industrial Product-service Systems Conference - PSS, industry transformation for sustainability and business. Retrieved January 28, 2018 from https://www.sciencedirect.com/science/article/pii/S2212827115001924

Huxtable, J., \& Schaefer, D. (2016). On Servitization of the Manufacturing Industry in the UK. Procedia CIRP, 52, 46-51. Retrieved January 24, 2019 from https://doi.org/10.1016/i.procir.2016.07.042

Jiang, H. (2013). Key Findings on Airplane Economic Life. Whitepaper, Boing Commercial Airplanes. $\begin{array}{lllll}\text { Retrieved June } & 7, & \text { from }\end{array}$ http://www.boeing.com/assets/pdf/commercial/aircraft economic life whitepaper.pdf.

Johnson Controls and Tyco (2016). Creating a Global Multi-Industrial Leader. Shareholder Presentation January 25, 2016. Retrieved April 28, 2017 from http://investors.johnsoncontrols.com/ /media/Files/J/Johnson-Controls-IR/reports-andpresentations/2016/ici-tyco-investor-presentation.pdf.

Kaufmann, T. (2015). Geschäftsmodelle in Industrie 4.0 und dem Internet der Dinge. Springer Fachmedien.

Kohtamäki, M., Partanen, J., Parida, V., \& Wincent, J. (2013). Non-linear relationship between industrial service offering and sales growth: The moderating role of network capabilities. Industrial Marketing Management, 42, 1374-1385. Retrieved June 8, 2018 from https://www.sciencedirect.com/science/article/pii/S001985011300148X

Kone (2017). Annual Review 2016. Retrieved June 04, 2018 from https://www.kone.com/en/Images/KONE Annual Review 2016 tcm17-37391.pdf

Kone (2018). Annual Review 2017. Retrieved June 04, 2018 from https://www.kone.com/en/Images/KONE Annual Review 2017 tcm17-68822.pdf

Kone (2019). Annual Review 2018. Retrieved May 17, 2019 from https://www.kone.com/en/Images/KONE Annual Review 2018 tcm17-78604.pdf

Kowalkowski, C., Gebauer, H., Kamp, B., \& Parry, G., (2017). Servitization and deservitization: Overview, concepts, and definitions. Industrial Marketing Management, 60, 4-10. Retrieved January 24, 2019 from https://doi.org/10.1016/j.indmarman.2016.12.007.

Lay, G., Copani, G., Jäger, A., \& Biege, S. (2010). The relevance of service in European manufacturing industries. Journal of Service Managementk, 21(5), 715-726. Retrieved January 28, 2018 from https://www.emeraldinsight.com/doi/pdfplus/10.1108/09564231011092908 
Lay, G. (2014). Servitization in Industry. Springer International Publishing.

Lee, J., Kao, H-A., \& Yang, S. (2014). Service innovation and smart analytics for Industry 4.0 and big data environment. Product Service Systems and Value Creation. Proceedings of the $6^{\text {th }} \mathrm{CIRP}$ Conference on Industrial Product-Service Systems. Retrieved January 17, 2019 from https://www.sciencedirect.com/science/article/pii/S2212827114000857.

Lee, J., Lapira, E., Bagheri, B., \& Kao, H. (2013). Recent advances and trends in predictive manufacturing systems in big data environment. Manufacturing Letters, 1(1), 38-41. Retrieved May 8, 2016 from https://www.sciencedirect.com/science/article/pii/S2213846313000114.

Levitt, T. (1960). Marketing Myopia. Harvard Business Review July-August 2004. Retrieved February 04, 2019 from https://s3.amazonaws.com/academia.edu.documents/37949698/1. Marketing Myopia.pdf?AW SAccessKeyld=AKIAIWOWYYGZ2Y53UL3A\&Expires=1549286526\&Signature=ZU4t9R7tr2j\% 2F9p2FVt5eDL5IOQU=\&response-content-disposition=inline\%3B filename=The Idea in Brief The Idea in Practice.pdf.

Lightfoot, H., Baines, T.S., \& Smart, P. (2013). The servitization of manufacturing A systematic literature review of interdependent trends. International Journal of Operations and Production Management, 11/12, 1408-1434. Retrieved January 17, 2017 from https://www.emeraldinsight.com/doi/pdfplus/10.1108/IJOPM-07-2010-0196.

Lohr, S. (2018). G.E. Makes a Sharp Pivot on Digital. Retrieved June 05, 2018 from https://www.nytimes.com/2018/04/19/business/ge-digital-ambitions.html.

Manufacturing USA Annual Report (2018). National Institute of Standards and Technology. Retrieved January 31, 2019 from https://nvlpubs.nist.gov/nistpubs/ams/NIST.AMS.600-3.pdf.

Martinsuo, M., Perminova-Harikoski, O., \& Turunen, T. (2015). Strategic Change Towards Future Industrial Service Business. Tampere University of Technology. Retrieved January 28, 2018 from

https://tutcris.tut.fi/portal/files/4274023/strategic change towards future industrial service bu siness.pdf.

Mathieu, V. (2001). Product services: from a service supporting a product to a service supporting a client. Journal of Business \& Industrial Marketing, 16-1, 39-61. Retreived February 3, 2019 from https://doi.org/10.1108/08858620110364873.

Meylan, G., Ehrat, M., Schmid, M., Frei, P., \& Qvist-Sørensen, P. (2019). Rückblick, Ausblick, Weitblick: Arbeitswelt 4.0 in der Schweizer MEM-Branche (to be published)

Mont, O. (2002). Clarifying the concept of product-service system. Journal of Cleaner Production, 10(3), 237-245. Retrieved June 02, 2018 from https://www.sciencedirect.com/science/article/pii/S0959652601000397.

Mont, O. (2006). Product-Service Systems: reviewing achievements and refining the research agenda. Journal for Cleaner Production 14, 1451-1454. Retrieved June 02, 2018 from https://www.sciencedirect.com/science/article/pii/S095965260600076X.

Muro, M., Rothwell, J., Andes, S., Fikri, K., \& Kulkarni, S. (2015). America's Advanced Industries. The Brookings Institution. Retrieved January 28, 2018 from https://www.brookings.edu/research/americas-advanced-industries-what-they-are-where-theyare-and-why-they-matter/.

OECD (2017). The Next Production Revolution, Implications for Governments and Business. OECD Publishing. 
Opresnik, D., \& Taisch, M. (2015). The value of Big Data in servitization. International Journal of Production Economics 165, 174-184. Retrieved November 29, 2017 from https://www.sciencedirect.com/science/article/pii/S0925527314004307.

Poniszewska-Maranda, A., \& Kaczmarek, D. (2015). Selected method of artificial intelligence for Internet of Things conception. 2015 Conference on Computer Science and Information Systems, 1343-1348. Retrieved January 28, 2018 from https://www.researchgate.net/publication/300337706 Selected methods of artificial intelligen ce for Internet of Things conception.

Porter, M.E., \& Heppelmann, J.E. (2014). How Smart Connected Products Are Transforming Competition. Harvard Business Review, 92(11), 64-88. Retrieved January 28, 2018 from https://hbr.org/2014/11/how-smart-connected-products-are-transforming-competition.

Reinartz, W., \& Ulaga, W. (2008). How to Sell Services More Profitably. Harvard Business Review, 86(5), 90-6. Retrieved November 11, 2013 from http://hbr:org/2008/05/how-to-sell-servicesmore-profitably/ar/pr.

Rolls-Royce (2018). Rolls-Royce 2018 Half Year Results. Retrieved February 7, 2019 from https://www.rolls-royce.com/ /media/Files/R/Rolls-Royce/documents/investors/h1-2018-resultspresentation.pdf

Rolls-Royce (2018). Roll-Royce Holdings plc Annual Report 2017. Retrieved June 07, 2018 from https://www.rolls-royce.com//media/Files/R/Rolls-Royce/documents/annual-report/2017/2017full-annual-report.pdf.

Rolls-Royce (2016). Tom Palmer on Data Driven Aviation. Retrieved June 06, 2018 from https://www.rolls-royce.com/media/our-story/insights/2016/tom-palmer-on-data-driveaviation.aspx.

Rymaszewska, A., Helo, P., \& Gunasekaran, A. (2017). loT powered servitization of manufacturing - an exploratory case study. International Journal of Production Economics, 192, 92-105. Retrieved November 21 , 2017 from https://www.sciencedirect.com/science/article/pii/S0925527317300531.

Schindler (2018). Annual Report 2017 Financial Statements. Retrieved June 04, 2018 from https://www.schindler.com/content/com/internet/en/investorrelations/reports/ jcr content/contentPAR/downloadlist/downloadList/447 1519311411967.do wnload.asset.447 1519311411967/SchindlerAR2017 Financial Statements e.pdf.

Schindler (2013). Each day Schindler moves one billion people. Retrieved June 03, 2018 from https://www.schindler.com/content/dam/web/com/pdfs/reportfactsheets/2013/Schindler2013AR Group Review EN.pdf.

Schweder, J. (2017). Turning Out the Lights on the Factory Floor." Automation World. Retrieved June 04, 2018 from https://www.automationworld.com/article/technologies/robotics/turning-out-lightsfactory.

Scott, R.E. (2015). The Manufacturing Footprint and the Importance of U.S. Manufacturing Jobs. Economic Policy Institute, Briefing Paper 388. Retrieved January 28, 2018 from https://www.epi.org/publication/the-manufacturing-footprint-and-the-importance-of-u-smanufacturing-jobs/.

Siemens (2016). Siemens and IBM to bring Watson Analytics to MindSphere. Press release December 13, 2016. Retreived February 04, 2019 from https://www.siemens.com/press/pool/de/pressemitteilungen/2016/digitalfactory/PR2016120102 DFEN.pdf. 
Siemens (2018). Siemens and Atos reinforce their strategic cooperation. Press release March 26, 2018. Retrieved $\quad$ February $04, \quad 2019$ from https://www.siemens.com/press/pool/de/pressemitteilungen/2018/corporate/PR2018030227CO EN.pdf.

Slowey, L. (2017). Look who's talking: KONE makes elevator services truly intelligent with Watson loT. Retrieved June 03, 2018 from https://www.ibm.com/blogs/internet-of-things/kone.

UNIDO (2018). Industrial Development Report 2018, United Nations Industrial Development Organization. Retrieved January 31, 2019 from https://sustainabledevelopment.un.org/content/documents/2537IDR2018 FULL REPORT 1.p df.

Valtakoski, A. (2017). Explaining servitization failure and deservitization: A knowledge-based perspective. Industrial Marketing Management, 60, 138-150. Retrieved January 24, 2019 from https://doi.org/10.1016/j.indmarman.2016.04.009.

Vandermerwe, S. (1988). Servitization of Business: Adding Value by Adding Services. European Management Journal, 6(4), 314-324. Retrieved February 11, 2019 from https://www.sciencedirect.com/science/article/pii/0263237388900333

Voith (2016). Welcome to the Next 150 Years. Annual Report 2016. Retrieved April 28, 2018 from http://voith.com/corp-en/Voith GB 2016 e.pdf.

Voith (2017). Digital Transformation. Annual Report 2017. Retrieved June 07, 2018 from http://voith.com/corp-en/VZ annual-report-2017 en.pdf.

Voith (2018). Make the Difference. Annual Report 2018. Retrieved February 05, 2019 from http://voith.com/corp-en/VZ annual-report-2018 18 vvk en.pdf

Wade, M. (2015). Digital Business Transformation - A Conceptual Framework. Global Center for Digital Business Transformation. Retrieved January 28, 2018 from https://www.imd.org/researchknowledge/reports/framework/.

Zimmermann, J. (2010). Corporate Entrepreneurship at GE and Intel. Journal of Business Case Studies 6(5). $\quad$ Retrieved June $07, \quad 2018$ from https://www.researchgate.net/publication/298328994 Corporate Entrepreneurship At GE An d Intel.

Zurich Airport (2017) Facts and Figures 2017. Retrieved January 29, 2019 from https://www.zurichairport.com/the-company/zurich-airport-ag/facts-and-figures.

The research paper passed the review process. | Received: March 31, 2019; Revised: February 5, 2020; Accepted: February 5, 2020; Published: June 15, 2020. 